\title{
RESISTANCE OF POTATO CLONES TO NECROTIC RECOMBINANT STRAINS OF POTATO VIRUS Y (PVY)
}

\author{
Resistência de clones de batata a isolados necróticos recombinantes do vírus Y da batata (PVY)
}

\author{
Silvia Regina Rodrigues de Paula Ribeiro ${ }^{1}$, César Augusto Brasil Pereira Pinto², \\ Suellen Bárbara Ferreira Galvino Costa ${ }^{3}$, Mariney de Menezes ${ }^{4}$, Antonia dos Reis Figueira ${ }^{3}$
}

\begin{abstract}
The $R y_{a d g}$ allele is widely used by breeders to confer extreme resistance to all strains of PVY. However, the necrotic strain has increased recombination resulting in recent considerable losses in productivity. Thus far, not all necrotic recombinant strains of PVY have been tested for their reaction to the $R y$ gene. The objective of this study was to identify potato clones carrying the

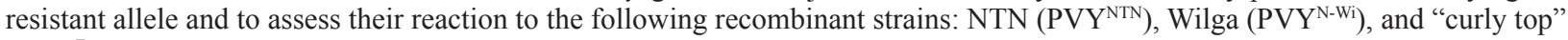
$\left(\mathrm{PVY}{ }^{\mathrm{E}}\right)$. Advanced clones from the potato breeding program at Universidade Federal de Lavras were evaluated through a specific molecular marker for the $R y_{a d r}$ allele. The clones carrying the resistance allele were grafted on tobacco plants infected with necrotic recombinant strains of PVY. The clones carrying the allele for resistance to PVY were not infected with any of the recombinants during the grafting test. These results confirm that resistance to necrotic recombinant strains has not yet been overcome and that the $R y_{a d g}$ allele also confers resistance to the three recombinant strains tested.
\end{abstract}

Index terms: Solanum tuberosum, viruses, breeding, genetic resistance.

\begin{abstract}
Resumo
O alelo $R y_{\text {adg }}$ é muito utilizado pelos melhoristas, por conferir resistência extrema a todas as estirpes do PVY. Entretanto, a estirpe necrótica possui grande capacidade de recombinação, de modo que, novos variantes genéticos capazes de provocar perdas consideráveis na produtividade, vêm surgindo recentemente. Até o momento, nem todas as estirpes recombinantes de PVY necrótico foram testados quanto à sua reação com o gene $R y$. Neste estudo, objetivou-se identificar clones de batata, portadores do alelo de resistência e avaliar a sua reação aos seguintes isolados recombinantes: NTN (PVY $\left.{ }^{\mathrm{NTN}}\right)$, Wilga (PVY $\left.{ }^{\mathrm{N}-\mathrm{Wi}}\right)$ e "top crespo" (PVY $\left.{ }^{\mathrm{E}}\right)$. Clones avançados de batata, do programa de melhoramento da Universidade Federal de Lavras, foram avaliados por meio de um marcador molecular específico para o alelo $R y_{a d g}$. Os clones portadores do alelo de resistência foram enxertados em plantas de fumo infectadas com o PVYN e três isolados recombinantes. Os clones portadores do alelo de resistência não foram infectados com nenhum dos recombinantes e nem com o PVYN no teste de enxertia. Esses resultados confirmam que o alelo $R y_{\text {adg }}$ confere resistência também aos variantes testados.
\end{abstract}

Termos para indexação: Solanum tuberosum, viroses, melhoramento, resistência genética.

\section{INTRODUCTION}

The Potato virus Y (PVY) is the most economically important virus in potato crops causing a series of symptoms that vary considerably due to the wide genetic variability that occurs within potato species. This variability occurs through phenomena such as mutation, recombination of genomic segments, and association of genomic segments, resulting in the emergence of new recombinant strains that are sometimes called genetic subgroups and which can cause considerable losses in production (Glais, Tribodet; Kerlan, 2002). The following three classical strains of PVY are the best known: $\mathrm{PVY}^{\mathrm{C}}, \mathrm{PVY}^{\mathrm{O}}$ and $\mathrm{PVY}^{\mathrm{N}}$. These strains were named according to the symptoms they cause in potato and tobacco (Nicotiana tabacum) plants, which are the main indicators of infection with these strains. In Hungary during the 1980s, Beczner et al. (1984) detected the first variant of PVY necrotic strains, called PVY ${ }^{\mathrm{NTN}}$, which is capable of causing necrotic ringspots (potato tuber ringspot disease; PTNRD) on the surface of tubers. When molecularly characterized, several PVYNTN isolates have been described as recombinant $\mathrm{PVY}^{\mathrm{N}}$ and $\mathrm{PVY} \mathrm{Y}^{\mathrm{O}}$ because they present three or four recombination junctions (RJs) in different regions of the genome (Glais; Tribodet; Kerlan, 2002; Nie; Singh; Singh, 2004; Lorenzen et al., 2006a; Kerlan et al., 2006; Schubert; Fomitcheva; Sztangret-Wisniewska 2007; Singh et al., 2008). Currently, this recombinant is described in several potato fields around the world, including Brazil,

${ }^{1}$ Universidade Federal de Lavras/UFLA - Departamento de Biologia/DBI - Campus UFLA - Cx. P. 3037 - $37.200-000$ - Lavras - MG - Brasil silviaribeiro@dbi.ufla.br

${ }^{2}$ Universidade Federal de Lavras/UFLA - Departamento de Biologia/DBI - Lavras - MG - Brasil

${ }^{3}$ Universidade Federal de Lavras/UFLA - Departamento de Fitopatologia/DFP - Lavras - MG - Brasil

${ }^{4}$ Universidade Federal de Lavras/UFLA - Departamento de Agricultura/DAG - Lavras - MG - Brasil

Received in january 13, 2014 and approved in july 14, 2014 
where several recombinant isolates have already been reported to exist throughout almost the entire country (Galvino-Costa et al., 2012a,b).

In Poland in 1991, another necrotic recombinant was detected for the first time in the Wilga cultivar and was named PVY "Wilga" (PVY ${ }^{\mathrm{N}-W_{\mathrm{W}}}$ ) (Chrzanowska, 1991). PVY ${ }^{\mathrm{N}-\mathrm{Wi}}$ may or may not cause symptoms in tubers. This recombinant also represents a combination of PVY ${ }^{\mathrm{O}}$ and $\mathrm{PVY}^{\mathrm{N}}$ genomic segments organized between two RJs with the major part of its genome belonging to the $\mathrm{PVY}^{\mathrm{O}}$ strain group, which explains the $\mathrm{O}$ serology found for these isolates. Although the PVY ${ }^{\circ}$ exerts a serological reaction, biologically it is able to induce vein necrosis in tobacco plants, which is a typical reaction reported for necrotic isolates. PVY isolates that share these same features have been reported in North American countries. However, the genomes of these PVY isolates have only one RJ and are named PVY ${ }^{\mathrm{N}: O}$ (Singh et al., 2008; Gray et al., 2010).

In addition to the main recombinant strains, $\mathrm{PVY}^{\mathrm{NTN}}$ and $\mathrm{PVY}^{\mathrm{N}-\mathrm{Wi}} / \mathrm{PVY}^{\mathrm{N}: \mathrm{O}}$, at least three more recombinant types have been classified as belonging to the PVY necrotic group. One of these types, namely PVY ${ }^{\mathrm{NE}-11}$ (Lorenzen et al., 2008), is considered a recombinant isolate with an intermediate genome between the North American necrotic strain $\left(\mathrm{PVY}^{\mathrm{N}-\mathrm{NA}}\right)$ (Lorenzen et al., 2006b), the regular European PVYN strain (Glais; Tribodet; Kerlan, 2002) and an unknown PVY parental strain. The beginning of the PVY ${ }^{\mathrm{NE}-11}$ genome sequence is identical to that of $\mathrm{PVY}^{\mathrm{N}}$, and the subsequent nucleotides are similar to $\mathrm{PVY}^{\mathrm{NA}-\mathrm{N}}$, but the coat protein region is not similar to any previously described PVY sequence because the 3 'end region $(\mathrm{CP} /$ UTR) is unique to the PVY ${ }^{\mathrm{NE}-11}$ type. Another new PVY recombinant has been identified in Syria with a PVY ${ }^{\circ}$ serological behavior and an ability to induce necrotic symptoms in tobacco leafs and PTNRD in tubers. These serological and biological behaviors result from a recombination that occurred between the PVY ${ }^{\mathrm{NTN}}$ and $\mathrm{PVY}^{\mathrm{N}-\mathrm{Wi}_{\mathrm{i}}}$ types, which generated atypical Syrian isolates described above, and are denominated as PVY ${ }^{\mathrm{NTN}-\mathrm{NW}}$ (Ali et al., 2010). The most recently described PVY recombinant has been reported in Brazil, and this recombinant has a unique genomic structure composed of segments of the PVY $^{\mathrm{NTN}}$ and PVY ${ }^{\mathrm{NE}-11}$ genomes (Galvino-Costa et al., 2012a). These isolates have been known for a long time in the Brazilian fields as a "Potato Curly Top" virus due to the severe symptoms caused in infected potato plants (SouzaDias, 2006). The Brazilian recombinant was classified as $\mathrm{PVY}^{\mathrm{E}}$ based on the biological reaction induced in potatoes and in tobacco plants, and the genomic structure of this recombinant shows that the first part of the genome came from PVY ${ }^{\mathrm{NTN}}$ (P1; part of NIa) followed by two pieces of PVY ${ }^{\mathrm{NE}-11}$ (portions of NIa and NIb and the 3 'end of the NIb and CP genes) intercalated by one small segment of PVY ${ }^{\mathrm{NTN}}$ (portion of NIb). These two last recombinant strain types show that not only are non-recombinant PVY strains able to generate new recombinants in the Syrian and Brazilian isolates by themselves but that they can act as parents in secondary recombination events generating new types of recombinant isolates, such as PVY ${ }^{\mathrm{NTN}-\mathrm{NW}}$ and PVYE.

The differentiation among these recombinant strains is becoming more and more complicated, and the easiest and most effective methods of detection are those based on the molecular structure of the PVY genome. Several types of RT-PCR multiplex assays have been reported to be the simplest way to separate the PVY strains and its recombinants (Weidemann; Maiss, 1996; Weilguny; Singh, 1998; Boonham et al., 2002; Lorenzen et al., 2006a, b; Kogovšek et al., 2008). In Brazil, all the classical PVY strains $\left(\mathrm{PVY}^{\mathrm{C}}, \mathrm{PVY}^{\mathrm{O}}\right.$ and $\mathrm{PVY}^{\mathrm{N}}$ ) have been present since the beginning of the 1980s. In contrast, not all recombinant strains have been reported in the country. The following three recombinant strains are currently present in Brazil: $\mathrm{PVY}^{\mathrm{NTN}}, \mathrm{PVY}^{\mathrm{N}-\mathrm{W}_{1}} / \mathrm{PVY}^{\mathrm{N}: \mathrm{O}}$ and $\mathrm{PVY}^{\mathrm{E}}$, with PVY ${ }^{\mathrm{NTN}}$ being the predominant strain during the last decades (Ávila et al., 2009; Sawazaki et al., 2009; GalvinoCosta et al., 2012a, b).

Phytovirus control measures are essentially preventive and are extremely important in preventing or at least reducing losses in potato production. Thus, the most efficient control strategy is the incorporation of genetic resistance in commercial cultivars, thus decreasing the use of chemicals to control vectors, which has been inefficient.

Three $R y$ genes that confer resistance to PVY have been located by the molecular mapping of potato chromosomes. $R y_{\text {sto }}$ (also called $R y-f_{\text {sto }}$ ) from Solanum stoloniferum and $R y_{\text {adg }}$ from $S$. tuberosum ssp. andigena have been mapped on chromosomes XII (Flis et al., 2005; Song et al., 2005) and XI (Hämäläinen et al., 1997), respectively, and $R y_{c h c}$ derived from $S$. chacoense has been mapped at the end of chromosome IX (Sato et al., 2006). Brigneti, Garcia and Baulcombe (1997) showed that $R y_{\text {sto }}$ is also located in the same region as $R y_{a d g}$ on chromosome XI . However, Valkonen et al. (2008), using markers developed for gene mapping experiments in $R y_{a d g}$ S. stoloniferum, could not confirm the $R y_{\text {sto }}$ gene location on chromosome XI in potatoes. 
There are available molecular markers for the $R y_{\text {adg }}$ and $R y_{\text {sto }}$ genes that can select genotypes that are resistant to PVY. Sorri, Watanabe and Valkonen (1999) identified a CAPS marker, which is designated ADG2/ $\mathrm{B} b v \mathrm{I}$, linked to the $R y_{\text {adg }}$ resistance gene and Kasai et al. (2000) developed the SCAR markers, RYSC3 and RYSC4, for the same gene (RYSCR), which has been widely used by plant breeders for its high selection efficiency and with different objectives as follows: determining the genetic constitution of PVY-resistant clones derived from two-parent crosses through the analysis of progeny (Ribeiro et al., 2006; Andrade et al., 2009 ), screening of PVY resistance genes in GenBank (Dalla Rizza et al., 2006; Whitworth et al., 2009) and detecting markers that are closely linked to genes imparting resistance to multiple pathogens, including the $R y_{a d g}$, Grol (confers resistance to nematodes of the Globodera genus) and $R x 1$ genes for extreme resistance to PVX (Gebhardt et al., 2006). Ottoman et al. (2009) also used this marker for the validation and implementation of marker-assisted selection in the selection of tetraploid potato genotypes in breeding programs.

For the $R y_{\text {sto }}$ gene, Song et al. (2005) found a polymorphism in the $\mathrm{F}_{1}$ segregating population and parental clones using the SSR primer pair, ST M0003 (Milbourne et al., 1998), and Cernák et al. (2008) developed a SCAR marker linked to the $R y_{\text {sto }}$ gene based on sequence information for the RAPD marker linked to the gene.

Due to the recent emergence of several new PVY recombinant strains, it is necessary to verify whether the $R y_{\text {adg }}$ resistance allele only provides protection to nonrecombinant PVY strains or if the new recombinant types will be able to overcome the resistance conferred by this gene. Therefore, the selection of potato clones carrying the $R y_{\text {adg }}$ allele and the subsequent evaluation of the biological reaction induced by the necrotic recombinant strains of PVY in these clones are considered to be valuable goals for potato breeding programs. In addition to the genomic recombination, the new PVY recombinant strains may have single or multiple mutations throughout their genomes that sometimes modify the amino acid sequences and potentially culminate in different proteins. Because any genetic determinants in the PVY genomes were once defined as being responsible for the necrotic PVY phenotypes induced in potato cultivars, it is impossible to predict how the plants carrying the resistance mediated by $R y_{a d g}$ gene will behave when infected with the PVY recombinants. Several potential genetic determinants have been reported (Tribodet et al., 2005; Hu et al., 2009), but no final conclusion has been made.
The objectives of this study were to identify potato clones carrying the $R y_{a d g}$ allele and to assess its efficiency in controlling resistance to the new recombinant strains of PVY, namely NTN (PVY $\left.{ }^{\mathrm{NTN}}\right)$, Wilga (PVY ${ }^{\mathrm{N}-\mathrm{Wi}}$ ) and "curly top" $\left(\mathrm{PVY}^{\mathrm{E}}\right)$.

\section{MATERIAL AND METHODS}

The present study was conducted in greenhouses located in the Departments of Plant Pathology and Biology in the Laboratory of Molecular Genetics (DBI) and the Laboratory of Molecular Virology (DFP) located at the Universidade Federal de Lavras (UFLA).

Thirty seven clones from the UFLA potato breeding program were evaluated, namely, OAS (Silva, Pinto; Figueira, 2000), JUG (Gadum; Pinto; Diniz, 2003) and MCR (Diniz, Pinto; Lambert, 2006). All of these clones originated from biparental crosses between clones immune to viruses $\mathrm{X}$ and $\mathrm{Y}$ in simplex conditions. Moreover, these clones also present other traits of interest, such as early maturity, heat tolerance, resistance to early blight (Alternaria solani) and resistance to nematodes (CIP, 1990). CBM clones were also evaluated (Menezes; Pinto; Lambert, 2001) even though they have not been assessed for any of the important potato viral diseases. The CBM clones were derived from biparental crosses involving the heat tolerant clones LT-7, LT-8, LT-9 (having immunity to virus $\mathrm{X}$ and $\mathrm{Y}$ ) and DTO-28 from the Centro Internacional de La Papa (CIP) crossed with Desireé, Baraka, Aracy, Itararé and Baronesa cultivars at the UFLA.

Three tubers from each clone were subjected to a DAS-ELISA serological test (Clark; Adams, 1977) employing polyclonal antiserum (Bioreba) specific to PVY and also to the PLRV, PVX and PVS viruses. All clones were also subjected to a molecular test to ascertain the presence or absence of the $R y_{a d g}$ resistance allele. The SCAR primer pair, RYSC3 (Kasai et al., 2000), was used as a specific marker for the $R y_{a d g}$ allele. The Chiquita cultivar was used as a PVY-susceptible control, and the XY9 clone was used as a PVY-resistant control.

DNA extraction followed the methodology described by Ferreira and Grattapaglia (1998) with modifications. PCR was set up with a total volume of 20 $\mu \mathrm{L}$ as follows: $4.0 \mu \mathrm{L}$ of $5 \mathrm{X}$ PCR Buffer; $1.2 \mu \mathrm{L}$ of $\mathrm{MgCl}_{2}$ $(25 \mathrm{mM}) ; 4 \mu \mathrm{L}$ of dNTPs $(10 \mathrm{mM}) ; 1.0 \mu \mathrm{L}$ of each primer; $0.25 \mu \mathrm{L}$ of Go Taq ${ }^{\circledR}$ flexi DNA polymerase; and $1 \mu \mathrm{L}$ of genomic DNA. Ultrapure water was used to make up the total volume of the reaction. The following program was used for PCR reactions: $95^{\circ} \mathrm{C}$ for 2 minutes for initial denaturation; 30 cycles at $95^{\circ} \mathrm{C}$ for 1 minute, $50^{\circ} \mathrm{C}$ for 45 
seconds and $72^{\circ} \mathrm{C}$ for 45 seconds; and $72^{\circ} \mathrm{C}$ for 7 minutes for final extension. The products obtained from this DNA amplification reaction were analyzed by electrophoresis using agarose gels stained with $1 \%$ GelRed Nucleic Acid Gel Stain.

\section{Evaluation of clones resistant to necrotic recombinant strains of PVY}

Clones that showed a specific band for the $R y_{\text {adg }}$ alleles were tested by grafting to tobacco plants (Nicotiana tabacum cv. Turkish NN-TNN) infected with the recombinant strain of PVY from the virus collection of the Department of Plant Pathology/UFLA. The following virus isolates were used: (1) the MU-AGA (NTN1) and $\mathrm{Y}^{\mathrm{N}} \mathrm{MG}$ (NTN2) isolates representing the PVY ${ }^{\mathrm{NTN}}$ (NTN) recombinant group (Galvino-Costa et al., 2012b); (2) the MFE-AGA isolate representing $\mathrm{PVY}^{\mathrm{N}-\mathrm{Wi}_{\mathrm{i}}}$ (Wilga) (Galvino-Costa et al., 2012b); and (3) the PVY-AGA isolate representing the new type of recombinant strain PVYE (Galvino-Costa et al., 2012a). These specific isolates were chosen because they represent the different types of recombinant strains reported in Brazil. The PVY ${ }^{\mathrm{NTN}}$ group has two representative isolates because the first $\left(\mathrm{Y}^{\mathrm{N}}-\mathrm{MG}\right)$ is a regular PVY ${ }^{\mathrm{NTN}}$ while the second (MU-AGA) has an unusual serological reaction with a $\mathrm{PVY}^{\mathrm{N}}$-specific monoclonal antibody (SASA-N) despite having a NTN genome. This behavior may be due to a point mutation located in the CP gene, as has been described for the PVYAST isolate recently studied in Brazil (Galvino-Costa et al., 2012a).

In the greenhouse, tobacco seedlings were mechanically inoculated with the necrotic recombinant PVY isolates when they reached the three- or four-leaf stage. Two tobacco plants were used for each clone and control sample in each group of recombinant strains. Fifteen certifiedhealthy potato tubers from the Ágata cultivar (susceptible) were planted as control samples along with 15 tubers of the XY9 clone with immunity to PVY.

The plants were observed until the onset of typical symptoms induced by the inoculated virus, at which point grafting was performed on top of infected tobacco plants. After 30 to 40 days, the leaves of grafted stems were subjected to a DAS-ELISA to test whether there was translocation of the virus.

\section{RESULTS AND DISCUSSION}

\section{Serologic Test: DAS-ELISA}

Based on serological results, the positive reaction against the PVY polyclonal antibody occurred for two of 12 OAS clones, five of $20 \mathrm{JUG}$ clones and one of five MCR clones. Among all clones, only JUG 6-19 was infected with PVX suggesting that some clones have the allele for resistance to virus $\mathrm{Y}$ and even PVX. In contrast, the CBM clones showed a high frequency $(16 / 31)$ of infection with PVY.

For the $\mathrm{S}$ virus, all CBM, OAS, JUG (except JUG 6-17) and MCR clones showed a positive reaction and high values of absorbance in the test, which commonly occurs with materials that have been multiplied many times in the field.

Although serologic testing was performed for the four viruses, this study considered only the reaction of clones to PVY. Even clones that showed a positive reaction to PVY underwent molecular testing for the $R y_{\text {adg }}$ allele to avoid false positives, which can occur in such tests.

\section{Identification of clones carrying the $\boldsymbol{R} \boldsymbol{y}_{\text {adg }}$ allele}

The RYCS3 marker for the allele that confers extreme resistance to PVY $\left(R y_{a d g}\right)$ produces a single band of $321 \mathrm{bp}$, which is absent in susceptible genotypes. Of the $31 \mathrm{CBM}$ clones, seven were carriers of the $R y_{a d g}$ allele (Figure 1A). For the other clones, the proportions were 8/12 for OAS (Figure 1B), 4/5 for MCR (Figure 1C) and 15/20 for JUG (Figure 1D). This result was expected in light of the OAS, JUG and MCR clones being descendants parents with resistance to this virus. In contrast, the majority of the CBM clones did not show the band for the $R y_{\text {adg }}$ allele.

According to Cockerham (1970), Ry genes control a type of extreme resistance that provided complete protection to all PVY strains tested at the time of the study, which likely included only the non-recombinant strains $\left(\mathrm{PVY}^{\mathrm{C}}, \mathrm{PVY}^{\mathrm{O}}\right.$ and $\mathrm{PVY}^{\mathrm{N}}$ ) that had been reported. The most widely used gene in breeding programs is $R y_{a d g}$ gene, which originates from $S$. tuberosum spp. andigena (Muñoz, Plainsted; Thurston 1975) and the $R y_{\text {sto }}$ gene, which originates from S. stoloniferum (Cockerham, 1970). These two genes have the advantage of conferring resistance to PVY in its simplex form (Ry ry ry ry). In the absence of contradictory reports, these genes are assumed to be quite stable. They are, therefore, unlike other genes such as $N y_{t b r}$ (Beemster, De Bokx, 1987), which is found in cultivars such as Pentland Crown and in wild species, including S. chacoense, S. demissum, and S. tuberosum ssp. andigena (Cockerham, 1970), whose resistance has been overcome by the $\mathrm{PVY}^{\mathrm{N}}$ strain, Baldauf (2006) also demonstrated that the $N y_{t b r}$ gene, which is found in the Allegany cultivar, had its resistance overcome by various American isolates of PVY. However, no isolate that causes necrosis in the tubers of the Yukon Gold cultivar is able to overcome the resistance conferred by the $R y_{\text {adg }}$ gene. 


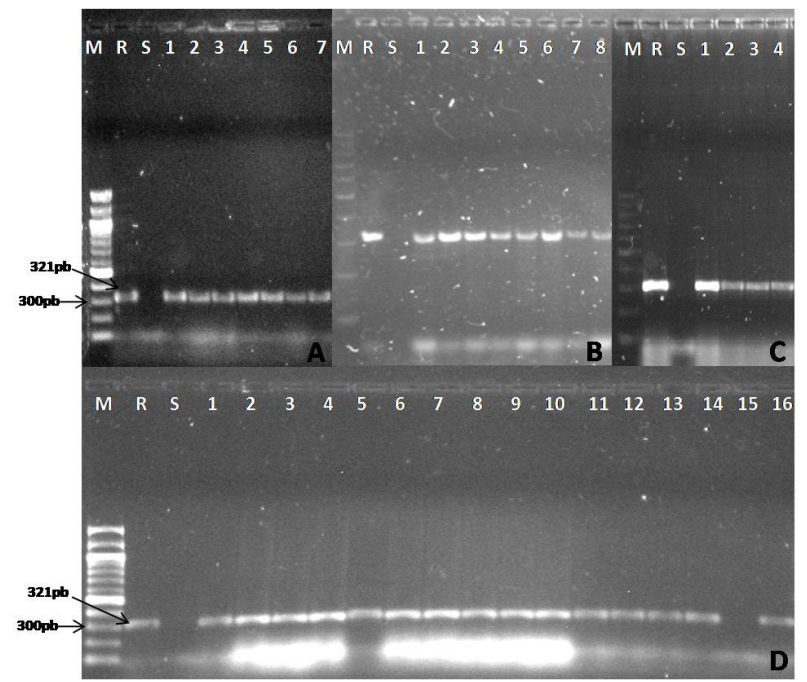

Figure 1 - Electrophoretic analysis of the band amplified with primers designed by Kasai et al. (2000). M-100bp DNA Ladder Marker; R-XY9 (resistant control), S-Chiquita (susceptible control); A - 1-CBM 4-42; 2CBM 9-10; 3-CBM 9-28; 4-CBM 18-11; 5-CBM 19-11; 6-CBM 22-19; 7-CBM 24-06. B- 1-OAS 1-120; 2-OAS 1-28; 3-OAS 2-74; 4-OAS 2-111; 5- OAS 2-103; 6-OAS 3-30; 7-OAS 4-40; 8-OAS 4-68. C - 1-MCR 13-58; 2-MCR 14-76; 3-MCR 14-106; 4-MCR 17-02. D - 1-JUG 1-03; 2-JUG 1-05; 3-JUG 1-09; 4-JUG 1-10; 5-JUG 2-15; 6-JUG 2-20; 7-JUG 2-28; 8-JUG 3-12; 9-JUG 3-09; 10JUG 3-11; 11-JUG 4-02; 12-JUG 5-08; 13-JUG 5-25; 14-JUG 5-06; 15-JUG 6-19 (susceptible); 16-JUG 6-01.

Molecular marker-assisted selection (MAS) has been widely used in breeding programs due to the speed and efficiency with which carriers of disease resistance alleles can be identified by this method. For PVY, some molecular markers for resistance to this virus have already been developed. Using RFLP analysis, Hämäläinen et al. (1997) identified a marker on chromosome XI, TG508, which is strongly linked to the $R y_{\text {adg }}$ locus at an estimated distance of $2 \mathrm{cM}$. This marker has been used to develop a DNA fragment, ADG2, which is located in a family of resistance genes on chromosome XI (Hämäläinen et al., 1998). From this DNA fragment, Sorri, Watanabe and Valkonen (1999) developed a CAPS marker designated ADG2/BbvI, which is linked to the $R y_{\text {adg }}$ resistance gene. This marker amplifies an undigested product of $355 \mathrm{bp}$, which is associated with resistance to PVY (via the $R y_{a d g}$ gene), and digestion with the $\mathrm{B} b v \mathrm{I}$ enzyme produces two bands of 270 and $85 \mathrm{bp}$, which are associated with susceptibility to PVY.
The most efficient molecular marker for PVY resistance is the SCAR marker (RYSC3) developed by Kasai et al. (2000). This marker is found within the $R y_{a d g}$ gene, which makes it ideal for selecting genotypes resistant to this virus because no recombination between the gene and the band can occur. Besides, the amplified band was sharp in resistant individuals and absent in susceptible ones, thereby making it easy to use in potato breeding. These results highlighted the efficiency of this marker and agreed with other studies in literature where the efficiency of the marker in detecting resistant genotypes has been estimated at 99,7\% (Boris et al., 2009; Whitworth et al., 2009).

Hämäläinen et al. (1998) mechanically inoculated $\mathrm{PVY}^{\mathrm{N}}$ and $\mathrm{PVY}^{\mathrm{O}}$ isolates by grafting the parents and progeny from crosses between genotypes of potato (Solanum tuberosum spp. andigena) carrying the $R y_{a d g}$ allele and the 84.194 .30 clone, both of which are diploid and come from CIP (Peru). Individuals who showed no symptoms of the inoculated strains were submitted to the serological test with negative results, thereby demonstrating that they should possess the resistance gene derived from the resistant parent and that this gene confers the type of extreme resistance seen in individuals resistant to $\mathrm{PVY}^{\mathrm{N}}$ and $\mathrm{PVY}^{\mathrm{O}}$. Similar results have been obtained by Gebhardt et al. (2006), who used the same parents of this cross but inoculated by grafting other isolates of $\mathrm{PVY}^{\mathrm{N}}$. The ELISA test was performed three to five weeks after grafting and identified the negative individuals who underwent evaluation with the RYSC3 molecular marker, which indicated the presence of the 321 bp band characteristic of the $R y_{a d g}$ allele. In the present study, all clones that showed this band were resistant when inoculated with all PVY isolates tested.

\section{Evaluation of the biological reaction of the clones to the necrotic recombinant strains of PVY}

The results of the DAS-ELISA serological test performed on stem leaves 30 and 40 days after grafting onto tobacco plants infected with PVY necrotic strains and variants showed no translocation of the virus to the stems of the clones carrying the resistance allele. The test results were all negative and were confirmed by the absence of symptoms of the virus. The same result occurred for the XY9 resistant sample, but the opposite result occurred with the stems of $\mathrm{cv}$. Ágata, which tested positive in the serological test in response to grafting onto contaminated tobacco plants.

The symptoms presented by the stems of potato $\mathrm{cv}$. Ágata after fixation of the grafts were consistent with the typical symptoms of PVY. However, there were variations in intensity depending on the isolate of the virus used to inoculate the tobacco plants (Figure 2). The stems of the 
rootstock infected with the PVY ${ }^{\mathrm{NTN}-1}$ strain (Figure 2 - A1) showed a decrease in leaf area, which led to deformities and a moderate mosaic pattern. In contrast, the stems infected with PVY ${ }^{\mathrm{N}-W i}$ (Figure 2 - A2) did not suffer such growth impairment, and the mosaic pattern was light.

Because this experiment used only the stems of potato plants, the main symptom of PVY ${ }^{\mathrm{NTN}}$, namely, necrotic rings in tubers (potato tuber necrotic ringspot disease; PTNRD), could not be observed. However, we found severe mosaic patterns, decreased growth, severe leaf deformation and shriveled stems in plants infected with this isolate (Figure 2 - C1).

When the test sample was grafted onto susceptible tobacco plants infected with the PVY ${ }^{\mathrm{E}}$ recombinant, the new leaflets presented not only mosaic patterns but also leaf roll, dwarfism, drastically decreased leaf area and drastically decreased stem curling, which are symptoms characteristic of this variant known in Brazil as "Potato Curly Top" (Figure 2-D1).

The positive serological results together with the symptoms displayed by the susceptible control sample after grafting for all tested recombinant strains demonstrated that the absence of the $R y_{a d g}$ allele allowed translocation of the virus. The genotypes carrying the resistant allele did not present symptoms induced by any type of PVY (Figure $2-\mathrm{A} 2, \mathrm{~B} 2, \mathrm{C} 2$, and D2) and had negative reactions in the serological test performed against this virus.

Whitworth et al. (2009) evaluated the resistance derived from $S$, tuberosum spp, Andigena to PVY ${ }^{\mathrm{NTN}}$,
$\mathrm{PVY}^{\mathrm{N}-\mathrm{Wi}}$ and $\mathrm{PVY}^{\mathrm{O}}$ isolates from North America used in field inoculation through grafting, and they used three specific molecular markers for the $R y_{\text {adg }}$ allele. One such marker was RYSC3, which was also used in the present study. The results showed that individuals who possessed the three markers were also resistant to all isolates of PVY tested, including PVY ${ }^{\mathrm{N}-\mathrm{Wi}}\left(\mathrm{PVY}^{\mathrm{N}: \mathrm{O}}\right)$, which had not been evaluated before.

The necrotic recombinant strains of PVY: PVYNTN and $\mathrm{PVY}^{\mathrm{N}-\mathrm{Wi}_{\mathrm{i}}}$ have already been identified in potato cultivation areas in Brazil (Ávila et al., 2009; Sawazaki et al., 2009; Galvino-Costa et al., 2012a, b). The PVY ${ }^{\mathrm{E}}$ isolates were initially misidentified as PVY ${ }^{\mathrm{NE}-11}$ in 2009 because of the specific PVY ${ }^{\mathrm{NE}-11}$ fragments amplified by two primer pairs described by Lorenzen et al. (2008). Recently, a systematic study of these isolates, including the PVY-AGA isolate used in the present work, has shown that their genomes consist of a new type of genomic structure originating from a combination of the PVYNTN and PVY ${ }^{\mathrm{NE}-11}$ segments. The recombination event generated a new recombinant genome with two pieces belonging to PVY $^{\text {NTN }}$ (the first consisting of nt $1-6754$, and the second consisting of nt $7642-8118$ ) and another two pieces belonging to PVY ${ }^{\mathrm{NE}-11}$ (the first consisting of nt 6755 7641 , and the second consisting of nt 8118 - UTR5'). This type of structure has been associated with the PVYE genetic strain based only on biological features (Singh et al., 2008; Galvino-Costa et al., 2012a). Until now, these isolates have only been reported in Brazil.

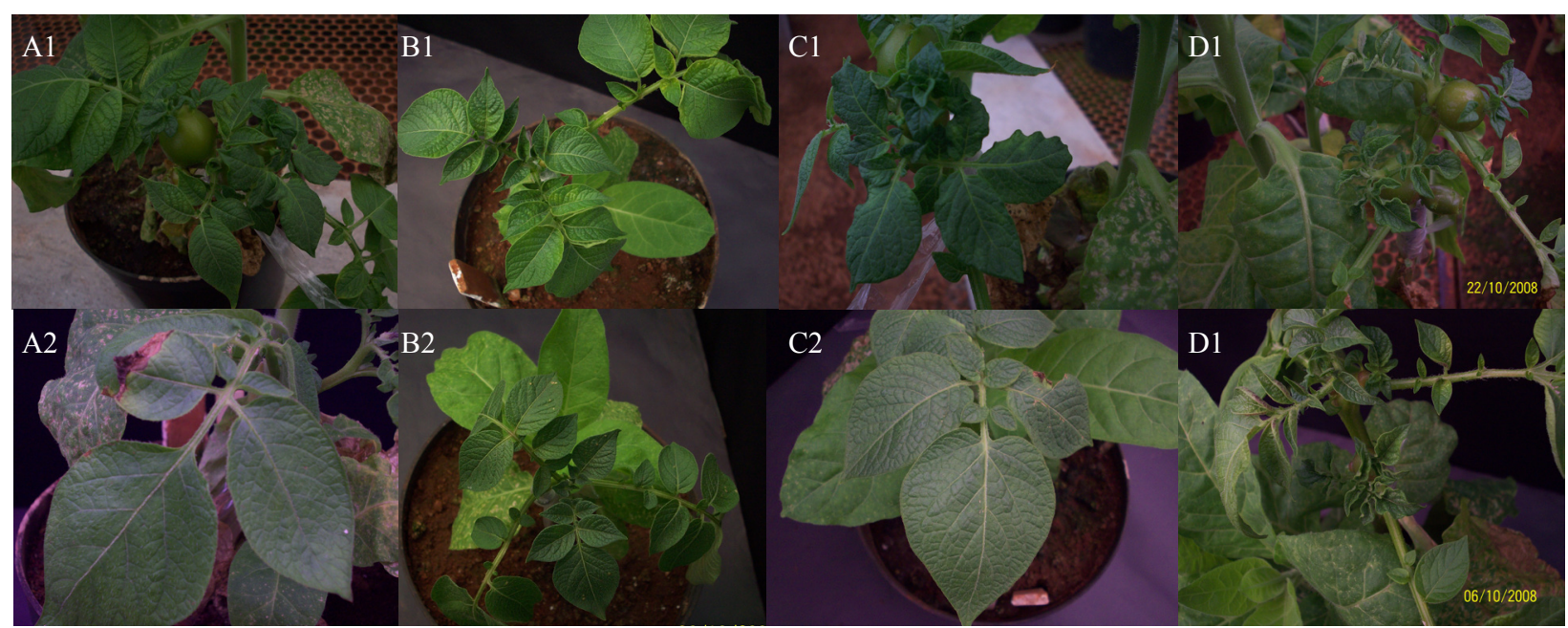

Figure 2 - Symptoms presented by potato stems used as controls susceptible to cv. Ágata (A1, B1, C1 and D1), and absence of symptoms in the stems of controls resistant to XY9 (A2, B2, C2 and D2) grafted onto tobacco plants infected with the following viruses: A, PVYNTN1; B, PVYN-Wi; C, PVYNTN2; and D, PVYE. 


\section{CONCLUSIONS}

We identified a number of clones bearing the $R y_{a d g}$ allele which can be used as parents to advance the potato breeding program.

The $R y_{a d g}$ allele confers resistance to necrotic strains of PVY and suggest that this resistance extends to the necrotic recombinant strains examined, namely, NTN $\left(\mathrm{PVY}^{\mathrm{NTN}}\right)$, Wilga $\left(\mathrm{PVY}^{\mathrm{N}-\mathrm{Wi}_{\mathrm{i}}}\right.$ ) and the new strain $\mathrm{PVY}^{\mathrm{E}}$, for which no evaluation of resistance has been reported.

\section{ACKNOWLEDGEMENTS}

The authors would like to thank the Foundation to Supporting Research in the State of Minas Gerais (FAPEMIG) for the post-doctoral scholarship and The National Council for Scientific and Technological Development (CNPq) and Coordination for the Improvement of Higher Education Personnel (Capes) for the funds used for this research.

\section{REFERENCES}

ALI, M.C.; MAOKA, T et al. PVY ${ }^{\mathrm{NTN}-\mathrm{NW}}$, a novel recombinant strain of Potato virus Y predominating in potato fields in Syria. Plant Pathology. 59:31-41, 2010.

ANDRADE, C.M. et al. Potato clones triplex for the $R y_{a d g}$ allele conferring resistance to Potato virus $\mathrm{Y}$ (PVY). Crop Breeding and Applied Biotechnology. 9(4):286-292, 2009.

ÁVILA, A.C. et al. Ocorrência de vírus em batata em sete estados do Brasil. Horticultura Brasileira. 27:490497, 2009.

BALDAUF, P.M. Biological and serological properties of Potato virus $Y$ isolates in northeastern United States potato. Plant Disease. 90(5):559-566, 2006.

BEEMSTER, A.B.R.; DE BOKX, J.A. Survey of properties and symptoms, In: DE BOKX, J.A.; VAN DER WANT, J.P.H. Viruses of potatoes and seedpotato production. 6:84-113, 1987.

BECZNER, L. et al. Studies on the etiology of tuber necrotic ringspot disease in potato. Potato Research. 27:339-352, 1984.

BOONHAM, N. et al. The detection of tuber necrotic isolates of Potato virus $\mathrm{Y}$ and the accurate discrimination of PVYO, PVYN and PVYC strains using RT-PCR. Journal of Virological Methods. 102:103-112, 2002.

BORIS, S.D. et al. Evaluation of a SCAR RYSC3 marker of the $R y_{\text {adg }}$ gene to select resistant genotypes to Potato virus Y (PVY) in the Inia potato breeding program. Chilean Journal of Agricultural Research. 69(3):305-315, 2009.

BRIGNETI, G.; GARCIA-MAS, J.; BAULCOMBE, D.C. Molecular mapping of the Potato virus $\mathrm{Y}$ resistance gene $R y_{\text {sto }}$ in potato. Theoretical and Applied Genetics. 94:198-203, 1997.

CIP - Centro Internacional de La Papa. Control de Infermedades Viróticas Y Similares. Informe anual 90, Lima, Peru, 1990. 103p.

CERNÁK, I. et al. Development of a locusspecific marker and localization of the $R y_{\text {sto }}$ gene on chromosome XII in tetraploid potato genome. Breeding Science. 58:309-314, 2008.

CHRZANOWSKA, M. New isolates of the necrotic strain of Potato virus $\mathrm{Y}\left(\mathrm{PVY}^{\mathrm{N}}\right)$ found recently in Poland. Potato Research. 34(2):179-182, 1991.

CLARK, M.F.; ADAMS, A.N. Characteristics of the microplate method of Enzyme-Linked Immunosorbent Assay for detection of plant viruses. Journal of General Virology. 34:475-483, 1977.

COCKERHAM, G. Genetical studies on resistance to potato viruses X and Y. Heredity. 25:309-348, 1970.

DALLA RIZZA, M. et al. Detection of PVY extreme resistance genes in potato germoplasm from the Uruguayan breeding program. American Journal of Potato Research. 83:297-304, 2006.

DINIZ, M.C.R.; PINTO, C.A.B.P.; LAMBERT, E.S. Sample size for family evaluation in potato breeding programs. Ciência e Agrotecnologia. 30(2):277-282, 2006.

FERREIRA, M.E. GRATTAPAGLIA, D. Introdução ao uso de marcadores moleculares em analise genética. 3rd edn, Embrapa-CENARGEN, Brasília, 1998. 220p. 
FLIS, B. et al. The $R y-f_{\text {sto }}$ gene from Solanum stoloniferum for extreme resistance to Potato virus Y maps to potato chromosome XII and is diagnosed by PCR marker GP122718 in PVY resistant potato cultivars. Molecular Breeding. 15:95-101, 2005.

GADUM, J.; PINTO, C.A.B.P.; DINIZ, M.C.R. Desempenho agronômico e reação de clones de batata (Solanum tuberosum L,) ao PVY. Ciência e Agrotecnologia.1484-1492, 2003.

GALVINO-COSTA, S.B.F. et al. Molecular and serological typing of Potato virus $\mathrm{Y}$ isolates from Brazil reveals a diverse set of recombinant strains. Plant Disease. 96:1451-1458, 2012a.

GALVINO-COSTA, S.B.F. et al. A novel type of Potato virus $\mathrm{Y}$ recombinant genome, determined for the genetic strain PVYE. Plant Pathology. 61:388398, 2012b.

GEBHARDT, C. et al. Marker-assisted combination of major genes for pathogen resistance in potato.

Theoretical and Applied Genetics. 112:1458-1464, 2006.

GLAIS, L.; TRIBODET, M.; KERLAN. C. Genomic variability in Potato potyvirus Y (PVY): evidence that $\mathrm{PVY}^{\mathrm{N}-\mathrm{W}}$ and $\mathrm{PVY}^{\mathrm{NTN}}$ variants are single to multiple recombinants between $\mathrm{PVY}^{\mathrm{O}}$ and $\mathrm{PVY}^{\mathrm{N}}$ isolates.

Archives of Virology. 147:363-378, 2002.

GRAY, S. et al. Potato virus Y: an evolving concern for potato crops in the United States and Canada. Plant Disease. 94:1384-1397, 2010.

HÄMÄLÄINEN, J.H. et al. Mapping and markerassisted selection for a gene for extreme resistance to Potato virus Y. Theoretical and Applied Genetics. 94:192-197, 1997.

.Molecular examination of a chromosome region that controls resistance to potato $\mathrm{Y}$ and $\mathrm{A}$ potyviruses in potato. Theoretical and Applied Genetics. 96:1036-1043, 1998.

HU, X. et al. A novel recombinant strain of Potato virus $\mathrm{Y}$ suggests a new viral genetic determinant of vein necrosis in tobacco. Virus Research. 143:6876, 2009.
KERLAN, C. Description of Plant Viruses: Potato virus Y, Association of Applied Biologists, 2006. Disponível em: http://www.dpvweb.net/dpv/showdpv. php?dpvno=414 Acesso em: 20 set. 2010.

KASAI, K. et al. Development of SCARS markers to the PVY resistance gene $R y_{\text {adg }}$ based on a common feature of plant disease resistance genes. Genome. 43(1):1-8, 2000.

KOGOVŠEK, P. et al. Single-step RT real time PCR for sensitive detection and discrimination of Potato virus Y isolates. Journal Virological Methods. 149:1$11,2008$.

LORENZEN, J.H. et al. Whole genome characterization of Potato virus $\mathrm{Y}$ isolates collected in the western USA and their comparison to isolates from Europe and Canada. Archives of Virology. 151:1055-1074, $2006 a$.

. A multiplex PCR assay to characterize Potato virus $\mathrm{Y}$ isolates and identify strain mixtures. Plant Disease. 90:935-940, 2006b.

. NE-11 represents a new strain variant class of Potato virus Y. Archives of Virology. 153:517-525, 2008.

MENEZES, C.B.; PINTO, C.A.B.P.; LAMBERT, E.S. Combining Ability of potato genotypes for cool and warm season in Brazil. Crop Breeding and Applied Biotechnology.1(2):145-157, 2001.

MILBOURNE, D. et al. Isolation, characterization and mapping of simple sequence repeat loci in potato. Molecular and General Genetics. 259:233-245, 1998.

MUÑOZ, F.J.; PLAINSTED, R.L.; THURSTON, H.D. Resistance to Potato virus Y in Solanum tuberosun ssp, andigena. American Potato Journal. 52(4):107-115, 1975.

NIE, X.; SINGH, R.P.; SINGH, M. Molecular and pathological characterization of $\mathrm{N}: \mathrm{O}$ isolates of the potato virus $Y$ from Manitoba, Canada, Canadian Journal of Plant Pathology. 26:573-583, 2004.

OTTOMAN, R.J. et al. Validation and implementation of Marker-Assisted Selection (MAS) for PVY resistance $\left(R y_{a d g}\right.$ gene) in a tetraploid potato breeding program. American Journal of Potato Research. 86:304-314, 2009. 
RIBEIRO, A.M. et al. SCAR marker for the selection of $R y$-duplex potato clones immune to Potato Virus Y. Crop Breeding and Applied Biotechnology. 6:1-8, 2006.

SATO, M. et al. Potato virus $\mathrm{Y}$ resistance gene, $R y_{\text {chc }}$, mapped to the distal end of potato chromosome 9 .

Euphytica.149:367-372, 2006.

SAWAZAKI, H.E. et al. Potato virus YNTN: a coat and $\mathrm{P} 1$ protein sequences analysis of a Brazilian isolate.

Potato Research. 52:379-392, 2009.

SCHUBERT, J.; FOMITCHEVA, V.; SZTANGRETWISNIEWSKA, J. Differentiation of Potato virus Y using improved sets of diagnostic PCR-primers. Journal of Virological Methods. 140:66-74, 2007.

SILVA, A.O.; PINTO, C.A.B.P.; FIGUEIRA, A.R. Identificação de clones de batata imunes aos vírus $\mathrm{X}$ (PVX) e Y (PVY), adaptados à região Sul de Minas Gerais, Summa Phytopathologica. 26(4):385-390, 2000.

SINGH, R.P. et al. Discussion paper: the naming of Potato virus $\mathrm{Y}$ strains infecting potato. Archives of Virology.1 53:1-13, 2008.

SONG, Y.S. et al. Mapping of extreme resistance to PVY $\left(R y_{s t o}\right)$ on chromosome XII using anther-culturederived primary dihaploid potato lines. Theoretical and Applied Genetics. 111:879-887, 2005.

SORRI, V.A.; WATANABE, K.N.; VALKONEN, J.P.T. Predicted kinase-3a motif of a resistance gene analogue as a unique marker for virus resistance. Theoretical and Applied Genetics. 99:164-170, 1999.
SOUZA-DIAS, J.A.C. Novo desafio: evidências apontam para a presença de uma estirpe exótica de PVY em lavouras de batata Monalisa na região de Casa Branca, São Paulo, Cultivar. 6(36):12-16, 2006.

TRIBODET, M. et al. Characterization of Potato virus $\mathrm{Y}$ (PVY) molecular determinants involved in the vein necrosis symptoms induced by PVYN isolates in infected Nicotiana tabacum cv, Xanthi. Journal of General Virology. 86:2101-2105, 2005.

VALKONEN, J.P.T. et al. Evidence for utility of the same PCR-based markers for selection of extreme resistance to Potato virus Y controlled by $R y_{\text {sto }}$ of Solanum stoloniferum derived from different sources. Annals of Applied Biology. 152:121-130, 2008.

WEIDEMANN, H.L.; MAISS, E. Detection of the potato tuber necrotic ringspot strain of Potato virus $\mathrm{Y}$ $\left(\mathrm{PVY}^{\mathrm{NTN}}\right)$ by reverse transcription and immunocapture polymerase chain reaction. Journal of Plant Disease and Protection. 103:337-345, 1996.

WEILGUNY, H.; SINGH, R.P. Separation of Slovenian isolates of PVY-NTN from the North American isolates of PVY-N by a 3-primer PCR. Journal of Virological Methods. 71:57-68, 1998.

WHITWORTH, J.L. et al. Characterization of broad spectrum Potato Virus Y resistance in a Solanum tuberosum ssp, andigena-derived population and select breeding clones using molecular markers, grafting and field inoculations. American Journal of Potato Research. 86:286-296, 2009. 